\title{
茶のフッ素含量に関する研究*
}

農林省茶業試験場 岡田文雄・古谷弘三

\section{Studies on Fluorine Content in Tea}

\author{
By Fumio OKADA and Kôzô FuruYA
}

\section{1 まえがき}

栽培される植物の中で茶はフッ素含量が多く，その含 量は土㙵の影響が大きいようである。

著者らは茶の新しい利用法を開発する目的で, 当場に 栽培されているやぶきた，はつるみじ，べにほまれの 3 品種, およびインスタント ティーについてフッ素含量 を調查し，さらに，肥料の種類による影響ああわせて検 討した。また，1/2000 a・ワグネルポットを用いて前記 の 3 品種を砂耕栽培し, 肥料を施用する際にフッ化ナト リウム水溶液を添加吸収させて, 茶樹のフッ素量の変化 を調ぺた。また, ポット栽培の結果を考慮し, さらに, 試験をほ場に移し，C17 系統（25年生）にフッ化ナトリ ウム水溶液をうね間に潅注して吸収させ，含有フッ素の 溶剤の違いによる溶出性を検討した。

てれらの結果をこてに一括して報告する。

なお, 肥料試験の試料は当場土袞肥料研究室からいた だいたあのである。

\section{2 分 析 方 法}

\section{1 試 料の調製}

試料はすべて粉末としその $5 \mathrm{~g}$ を用いた。

茶樹の各部位におけるフッ素分布については，樹齢 3 年生のぺにほまれを1964年 2 月 3 日に掘り取り, 水洗後 乾燥粉末にした。

インスタント ティーは多重段浸出凍結乾燥により製 造した。

\section{2 フッ素の定量法}

江見, 速水の Th-Neo-Thorin 比色法によって行なっ た。

概略はまず酸化カルシウム $0.3 \mathrm{~g}$ を試料に添加し, 蒸 留水で浸した後, 湯浴上で乾燥してマッフル $\left(600^{\circ} \mathrm{C}\right)$ で灰化した。この試料をケイフッ化水素酸蒸留法で蒸留 $(150 \mathrm{ml})$ し, 蒸留液の一部を比色に用いた。比色は Th-Neo-Thorin 指示薬により, $\mathrm{pH}=2.3$ で発色させ, 日立光電光度計 $\mathrm{EPO}-\mathrm{B}$ 型 (セル $30 \mathrm{~mm}$ ), 吸収波長 $570 \mathrm{~m} \mu$ の吸光度を測定して, 検量曲線を用いて定量し た。

\section{試薬}

標準フッ化ナトリウム溶液：市販の特級品を用い, フ ッ素量 $1 \mathrm{mg} / \mathrm{m} l$ とした。

硝酸トリウム溶液：市販の特級品を使用し，トリウム を $1.1 \mathrm{mg} / \mathrm{m} l$ とした。

ヒドロキシルアミン塩酸塩溶液：1\%水溶液。

塩酸 : 特級品の $N / 10$ 液。

Neo-Thorin 溶液 : $0.05 \%$ 水溶液。

\section{検 量 曲 線}

フッ化ナトリゥムにより $50 \mathrm{~m} l$ 中にフッ素が 0,10 , $20,30,40,50 \gamma$ 存在するような標準溶液を作り, NeoThorin 溶液, ヒドロキシルアミン溶液书よび, トリウ ム溶液をそれぞれ $1 \mathrm{~m} l$ 加え, Th-Neo-Thorin 比色法 により検量曲線を求めた。

ただし,フッ素溶液と硝酸トリウム溶液の濃度は 10 $\gamma / \mathrm{m} l$ と $110 \gamma / \mathrm{m} l$ である。

\section{3 分析 ${ }^{-1}$ 法の検討}

フッ素の回収之焼却温度の設定

フッ素の回収量について, 酸化カルシウム $0.3 \mathrm{~g} に フ$ ”素溶液 $1000 \mathrm{\gamma} / \mathrm{m} l$ を添加し, 湯浴上で乾燥後 $300 \mathrm{~m} l$ 容三ッロフラスコにとり, 硫酸 (比重1.6) $50 \mathrm{ml}$ を一度 に加え, 前述の蒸留装置 (写真 1 ) で回收した。

また, 試料の焼却は, 温度が高すぎるとルッボ皿と試 料が青みをおび，低温では黒く完全に灰白色化されな い。焼却温度の設定に当たって, 江見らは $650^{\circ} \mathrm{C} て ゙$ 行な っているが，使用したマッフルの形式の違いも考兑られ

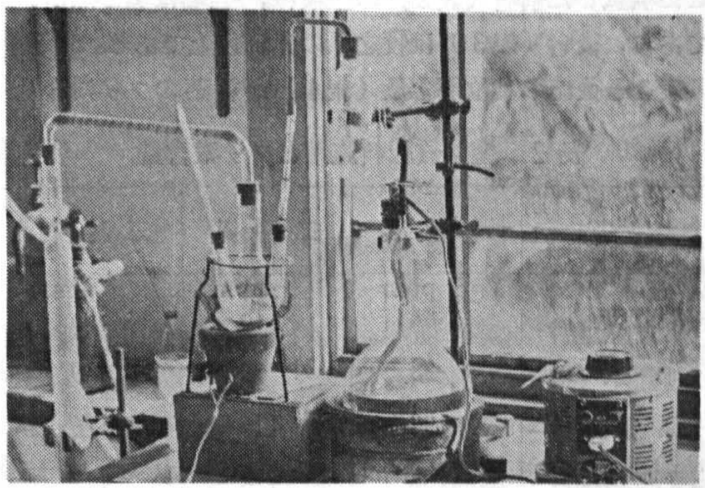

写真 1 フッ素蒸留装置

* 茶業技術研究 No. 37，32～38（1969）より転載 
たので，温度について再検討した。

却はあらかじめ $600^{\circ} \mathrm{C}$ および $650^{\circ} \mathrm{C}$ に上舁させた あので、30分閻燒却し，冷却したあのを測定した。

回收量に及ほす焼却温度の影響は表 1 のでとくであっ た。

表 1 回収量に及ぼす焼却温度の影響

\begin{tabular}{|c|c|c|c|}
\hline 燒却の有無 & 燒却温度 & 添 $\begin{array}{l}F- \\
\text { 加量 }\end{array}$ & 測 $\begin{array}{c}F- \\
\text { 定 值 }\end{array}$ \\
\hline . 热 & ${ }^{\circ} \mathrm{C}$ & $\begin{array}{l}1,000^{\gamma} \\
1,000\end{array}$ & $\begin{array}{l}992^{\gamma} \\
992\end{array}$ \\
\hline$\therefore \quad \cdot$ & 600 & $\begin{array}{l}1,000 \\
1,000\end{array}$ & $\begin{array}{l}1016 \\
1032\end{array}$ \\
\hline & 650. & $\begin{array}{l}1,000 \\
1,000\end{array}$ & $\begin{array}{l}904 \\
928\end{array}$ \\
\hline
\end{tabular}

その絬果, フッ菜の回収実験では添加量の99\%以上の 回収率が認められたが，塋却温度の影響は $650^{\circ} \mathrm{C}$ では試 料がやや青みを扎び，回収率は低く， $600^{\circ} \mathrm{C}$ が適当上思 われた。とれは使用したマッフルの温度計がろ内中央に あり，650 6 では高すぎるようで，以後の操作は $600^{\circ} \mathrm{C}$ で行なうことにした。

\section{3 ほ場試料による実験}

\section{3.: 1. 肥料の種類とフッ素含量}

茶園に施用される肥料の中で，リン酸肥料はフッ菜を 多量に含むため，予備的な実験として，茶のリン酸肥料 としてよく用いられる過リン酸石灰施用のもの上, 窒素 質肥料の違いについてフッ素含量を調査した。

測定結果として窐素質肥料との関係を表 2 ，過リン酸 石灰との関係を表 3 に示した。

茶のフッ素含量は裁培地の土增の影響が大きいが，乙 こに供試した前者（表 2）の土㙴は，当場ほ場の黑ボク であり，後者（表 3 ） は牧之原の赤黄色土である。

表 2 と後記の葉位別含量 (表4) から茶のフッ素含量

表 2 窒素質肥料施用とフッ素含量

\begin{tabular}{|c|c|c|c|}
\hline 萌料区別 & 一番茶 & 二番茶 & 三番茶 \\
\hline 硫 安 区 & $\begin{array}{l}\text { ppm } \\
84\end{array}$ & $\begin{array}{l}\text { ppm } \\
115\end{array}$ & $\begin{array}{l}\text { ppm } \\
136\end{array}$ \\
\hline 硝 安 区 & 98 & 94 & 119 \\
\hline 尿 素 区 & 92 & 115 & 126 \\
\hline 石灰室素区 & 105 & 128 & 117 \\
\hline
\end{tabular}

一注:されにほまれ 1960年
表 3 過リン酸不灰施用とフッ素含量

\begin{tabular}{|c|c|c|}
\hline 肥料区別 & 新 & 吉 \\
\hline 三 要絜 区 & $\begin{array}{l}\text { ppm } \\
140\end{array}$ & $\begin{array}{l}\text { ppm } \\
821\end{array}$ \\
\hline 無りン酸区 & 123 & 702 \\
\hline リン酸増施区 & 167 & 996 \\
\hline
\end{tabular}

注：やぶきた 1959年10月採取

は，窒素の形態による影響はほとんど見られないが，一 番茶に比べ二，三番茶の含量がやや多く，松浦らの報告 と同様な傾向がみられた。

過リン酸石灰施用（表3）のものは，無りン酸区より 三要素区，さらに，リン酸増施区と過リン酸石灰の施用 量が多い屯のほどフッ素含量は多く，乙の㑯向は新芽， 古葉टも同様であった。これはリン酸肥料に含まれるフ ッ素（通常リン鉱石中のフ、菜は $\mathrm{F} / \mathrm{P}_{2} \mathrm{O}_{5}$ で $0.07 \sim 0.1$ ) が茶に吸収されたためと思われる。

\section{2 茶樹の葉位別フッ素含量}

フッ美含量の茶期別ならびに茶の種類による差異が報 告されているが，葉位別については報告がないので一応 調查した。

試料は当場産のやぶきた，はつもみじ，べにほまれの 3 品種で，一番茶期に葉位別に摘みとり，それぞれのフ ッ素含量を測定した。

その結果を表 4 に，分散分析值（心～ 3 葉まで）を表 5 亿示す。

表 4 加ら明らかのように，葉位によってフッ素含量は 異なり，葉が成熟するに伴って增加することがみられた が, 心に多いのが特異的であった。なお，てれらの值に ついて分散分析を行なった結果，5\%の危険率で品種な らびに葉位に有意差が認められ，品種によって摘採日は

表 4 茶樹の葉位別フッ素含量

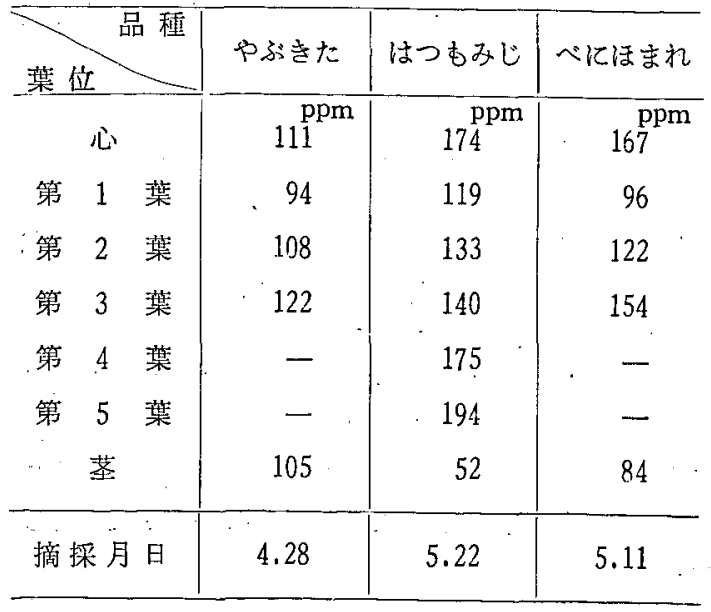

注 $:$ 1964年 
表 5 分 散 分 析

\begin{tabular}{lc|c|r|c}
\hline 要 & 因 & 自由 度 & 平均平方 & $F$ \\
\hline 全 & 体 & 11 & & \\
品 & 種 & 2 & 1196.08 & $5.94^{*}$ \\
葉 & 位 & 3 & 1301.09 & $6.46^{*}$ \\
誤 & 差 & 6 & 201.26 & \\
\hline
\end{tabular}

異なるが，葉位別の区間検定をみると，5\%の水集で心 $>$ 第 1 葉一第 2 葉, および，第 3 葉>第 1 葉之有意差が 認められた。

\section{3 茶樹のフッ素分布}

茶葉中のフッ素の含量については，そのだいたいの消 長が判明したので，さらに，他の部分にどのように含ま れているかを調査した。

ごにほまれ（樹舲 3 年生）を掘り取り（1964年 2 月 3 日) 水洗し，乙れを葉，荃，根の 3 器官とつぼみに分 け，さらに，葉を表6亿示したような生育期ごとに，ま た，茎は植付け時のものと，前年のもの $(\mathrm{A}+\mathrm{B}$ 茎)，当 年の生育期に区分し，根については径の太さによって細 根，中根扰よび太根に分け，計12区分について測定した。 その結果を表 6 亿示す。

フッ素は葉偮す最く，茎と根は大差がなかった。ま た，葉についてみると，さきの表 3 之同様 8 月以降化伸

表 6 茶樹の器官別およびその生育期別の フッ素含量

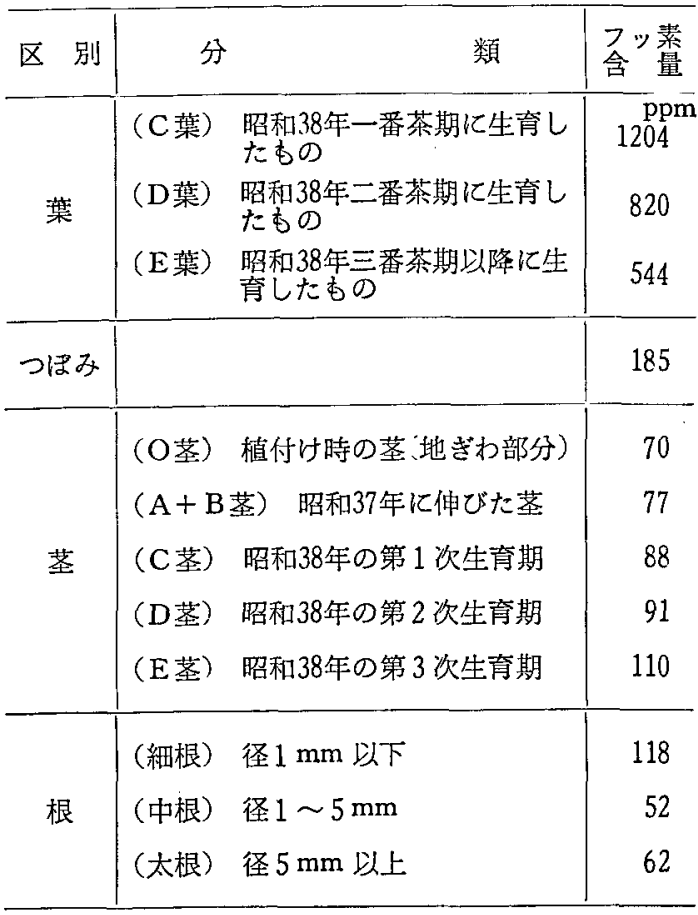

びた第 3 次生育期の若芽より，一番茶期に伸びた第 1 次 生育期の成葉に多く，さきの葉位別の测定値と考えあわ せると成熟するにしたがって增加するすのと思われる。

\section{4 インスタント ティーのフッ素含量}

茶のフッ素の利用に当たって，茶に含まれるフッ素が どの程度溶出するかが問題であり，さらに，その結合形 態が重要と思われる。

そこで1962年度当場産の煎茶，紅茶，ほうじ茶（いず れも一番茶）とセイロン紅茶＃19 さらに，乙れらから 製造したインスタント ティーのフッ菜量を調査した。 その值を表 7 亿示す。

茶のフッ絜の浸出量は抽出温度で巽なり，100ㄷ では 全体の約70\%の溶出が報告されている。インスタント ティーのフッ素含量も茶種によって異なるが，150～500 $\mathrm{ppm}$ と原料茶の3.0 4 5倍で，かなりの量が溶出するも のと思われる。特にセイロン紅茶とほうじ茶が多かった が，てれは原料茶のフッ素含量の相違だけでなく，浸出 度も考えられ，たとえば，可溶抽出残物は煎茶では約 45 \%であるが，ほうじ茶では約35\% 111 可溶分におりる浸出の難易も影響があると思われる。

表 7 原料茶とインスタント ティーの フッ素含有量

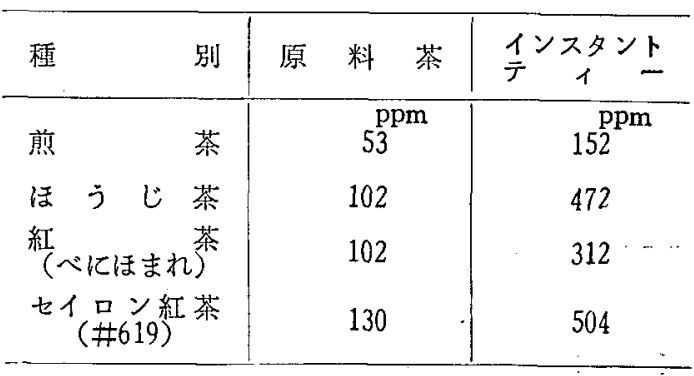

\section{4 ポットにおける施用実験}

\section{1 実 験 方 法}

火山灭土地帯ならびに，リン酸肥料施用試験の茶樹に フッ菜含量が多いととから，1964１966年にやぶきた， はつむみじ, べにほまれの 3 品種の 2 年生さし木苗を各

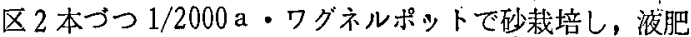
にフッ化ナトリウムを添加して，茶樹のフッ素吸収の状 態を調查した。なお，液肥は 1 ポット当たり $2 l$ を每週 1 回施用した。

1) フッ菜の施 用

フッ菜は液肥 $1 \mathrm{~m} l$ 当たり $2 \gamma$ を加えた。

2）陚料の調製

1964年の初年度は一番茶は中止して二番茶と三番茶を 摘採したが，二番茶は茶葉のみを，三番茶は 7 月以降生 育したもの全部を摘み取り，葉と木茎に分りて調査し た。また，1965 年，1966 年は各茶期の適期に摘採を行な ったが，その期日は表 8 のでとくである。 
表 8 摘採期 日

\begin{tabular}{l|c|c|c}
\hline 年度 & 1964 & 1965 & 1966 \\
茶期 & 月 日 & 月 日 & 月 10 \\
一 番 茶 & 一 & 5.12 & 5.12 \\
二 番 茶 & 7.10 & 6.29 & 7.14 \\
三 番 茶 & 11.6 & 8.7 & 8.19 \\
\hline
\end{tabular}

\section{2 実験結果と考察}

植付け当時と1966年の一番茶摘採後の生育状態は, 写 真 $2 ， 3 ， 4$ のごとくで, フッ素の施用が茶の生育に及 ほす悪影響はみられず，むしろ良好と思われた。

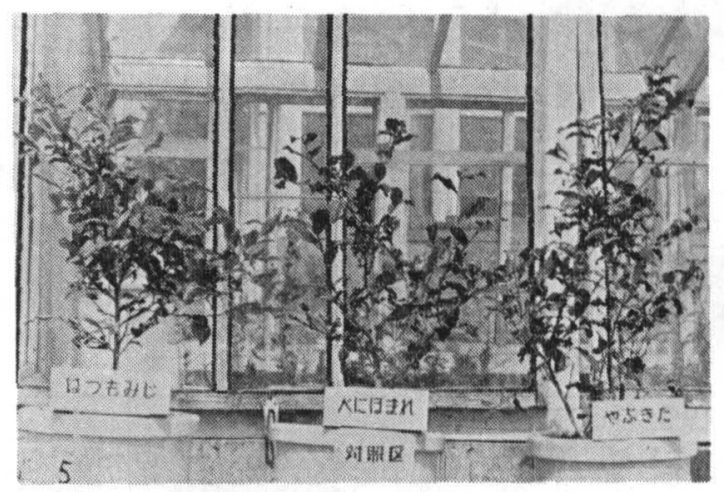

写真3 対 照 区

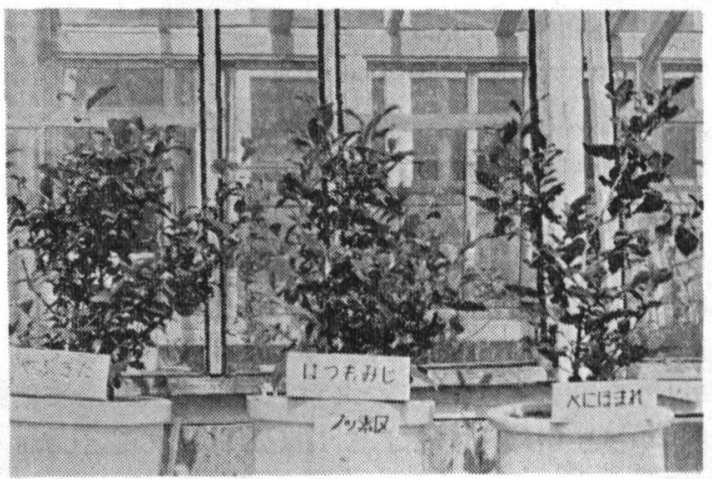

写真4 フッ素 区

写真 2 植付け時の生育状態

表 9 ポット試験による茶葉のフッ素含量

\begin{tabular}{|c|c|c|c|c|c|c|c|c|c|}
\hline \multirow{2}{*}{ 年 度 } & \multirow{2}{*}{\multicolumn{3}{|c|}{ 茶 期 }} & 対 & 照 & 区 & 7 & 素 & 区 \\
\hline & & & & やぶきた & はつあみじ & |べにほまれ & やぶきた & はつあみじ & ペにほまれ \\
\hline \multirow{4}{*}{1964} & \multirow{2}{*}{$=$} & \multirow{2}{*}{ 番 } & \multirow{2}{*}{ 茶 } & $\begin{array}{c}\mathrm{ppm} \\
160^{\circ}\end{array}$ & ${ }_{103^{\mathrm{ppm}}}$ & $123^{\mathrm{ppm}}$ & ${ }_{430^{\mathrm{ppm}}}$ & $\begin{array}{l}\mathrm{ppm} \\
400^{-1}\end{array}$ & $\begin{array}{l}\mathrm{ppm}_{695} \\
65^{2}\end{array}$ \\
\hline & & & & 117 & 126 & 100 & 540 & 505 & 517 \\
\hline & \multirow{2}{*}{$\equiv$} & \multirow{2}{*}{ 番 } & \multirow{2}{*}{ 茶 \{} & 127 & 202 & 112 & 819 & 796 & 842 \\
\hline & & & & 166 & 222 & 153 & 817 & 524 & 570 \\
\hline \multirow{6}{*}{1965} & \multirow{2}{*}{-} & \multirow{2}{*}{ 番 } & & 93 & 127 & 49 & 425 & 287 & 356 \\
\hline & & & & 181 & 88 & 82 & 425 & 247 & 枯 \\
\hline & \multirow{2}{*}{$=$} & \multirow{2}{*}{ 番 } & & 枯 & 85 & 57 & 334 & 351 & 137 \\
\hline & & & & 57 & 枯 & 110 & 396 & 166 & 114 \\
\hline & \multirow{2}{*}{$\equiv$} & \multirow{2}{*}{ 番 } & \multirow{2}{*}{ 茶 \{} & - & 90 & 90 & 342 & 244 & 310 \\
\hline & & & & 111 & - & 150 & 208 & 413 & 254 \\
\hline \multirow{6}{*}{1966} & \multirow{2}{*}{ - } & \multirow{2}{*}{ 番 } & \multirow{2}{*}{ 茶 } & 138 & 114 & 60 & 枯 & 264 & 234 \\
\hline & & & & 153 & - & 153 & 404 & 426 & - \\
\hline & \multirow{2}{*}{$=$} & \multirow{2}{*}{ 番 } & \multirow{2}{*}{ 茶 } & 159 & 159 & 72 & - & 184 & 204 \\
\hline & & & & - & - & 168 & 212 & 282 & - \\
\hline & \multirow{2}{*}{$\equiv$} & \multirow{2}{*}{ 番 } & \multirow{2}{*}{ 茶 \{} & 194 & 234 & 123 & 270 & 488 & 344 \\
\hline & & & & 231 & - & 132 & 234 & 307 & - \\
\hline
\end{tabular}


表 10 木荃のフッ素含量

\begin{tabular}{|c|c|c|c|c|}
\hline \multirow{2}{*}{ 品 種 区 別 } & \multicolumn{2}{|c|}{ 対 照 区 } & \multicolumn{2}{|c|}{ フッ菜区 } \\
\hline & 1 & 2 & 3 & 4 \\
\hline やぶきた & $\begin{array}{l}\mathrm{ppm} \\
97\end{array}$ & $\begin{array}{l}\mathrm{ppm} \\
88\end{array}$ & $\begin{array}{c}\mathrm{ppm} \\
148\end{array}$ & $\begin{array}{c}\text { ppm } \\
136\end{array}$ \\
\hline はつあみじ & 108 & 97 & 118 & 125 \\
\hline ペにほまれ & 89 & 67 & 135 & 105 \\
\hline
\end{tabular}

注：1964年11月 6 日

また，各品種の年度別ならびに茶期別のフッ素含量は 表 9，10のとおりであった。

その結果，茶期のフッ索は一部の欠測値を除いて，各 品種ともフッ菜の施用と無施用との間に明らかな違いが あり，フッ素を施用すると二，三の例外はあったが，対 照区に比べ 2〜6倍の増加が認められた。

また，1964年の木茎部分については，茶葉ほどの大差 はなかったがややはりフッ菜を施用したもののほうがや や多い傾向がみられた。

\section{5 ほ場における施用実験}

\section{1 実 験 方 法}

てれまでの実験結果から，茶樹のフッ菜含量は土壤の 影響だけでなく、リン酸肥料やフッ菜の施用により，あ る程度増加することが明らかとなったので，さらにほ 場でC17系統（25年生）について，茶传含まれるフッ菜 がどの程度溶出し，また，残留するかを検討した。

抽出は一般分析の常法に上るすのと，多重段浸出法に よるあのについて, 可溶分ならびにフッ素量を調査し た。

次いで1966年, 1967年には茶粉末 $2 \mathrm{~g}$ を $200 \mathrm{~m} l$ 容メス フラスコにひょう取し，有機溶郕（n-ブタノール，酢酸 エチル, アルコール，エーテル）あるいは熱湯を加えて 24時間浸出し，溶剤に浸出したものと，茶殼に残ったも のについてフッ素浸出状態を追求した。

\section{1）フッ素の施用}

1965年：フッ化ナトリウム溶液（フッ菜が $40 \mathrm{\gamma} / \mathrm{m} l$ ) を3 月下旬加ら10日置きに，1区当たり(156 $\left.\mathrm{m}^{2}\right) 20 乙$ を， 土境消毒用注入器でうねの両側飞注入した。しかし， 二,三番茶期には都合により土壤の表面に散布した。

1966年：一番茶期にはフッ素を $40 \mathrm{\gamma} / \mathrm{m} l$ としたが, 二, 三番茶期については 3 倍量の $120 \mathrm{r} / \mathrm{m} l$ とし, 1 区 当たり $120 \mathrm{\gamma} / \mathrm{m} l$ を 1 区当たり $40 l$ と增量し，うねの両 側に小溝を掘って潅注した。

2）試料の調製

年度ごとの一, 二, 三番茶の摘採期日は表11のこととく で，試料ははさみ摘みとし，製茶して分析に供した。
表 11 摘採 期 日

\begin{tabular}{|c|c|c|c|c|c|}
\hline 茶 & 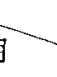 & 度 & 1965 & 1966 & 1967 \\
\hline - & 番 & 茶 & $\begin{array}{l}\text { 月 } \\
5.22\end{array}$ & $\begin{array}{l}\text { 月 } \\
5.11\end{array}$ & $\begin{array}{l}\text { 月 } \\
5.14\end{array}$ \\
\hline$=$ & 番 & 茶 & 7. 6 & 7. 2 & 6. 24 \\
\hline$\equiv$ & 番 & 茶 & 8. 9 & 8. 10 & 8. 6 \\
\hline
\end{tabular}

\section{2 実験結果と考察}

1965年，1966年の試験区別ならびに一，二，三番茶の 測定結果は表12のごとくで，1965年の完全抽出後の残留 フッ素量は表13のごとくであった。また，原料に対する 多重段抽出後の残留可溶分ならびに，フッ素量を示せば 表14のとおりである。

また，実験 $3 ， 5$ 抢よび $5 ， 2$ の調查でフッ素が熱湯 中にかなり溶出することが認められたので，1966年の 二, 三番茶と1967年に，フッ素の形態について有機溶剂 を用いて検討した。その結果を表 15 に示す。

表 12 ほ場試験のフッ素含量

\begin{tabular}{|c|c|c|c|c|c|c|}
\hline \multirow[b]{2}{*}{ 茶 期 } & \multicolumn{2}{|c|}{$\begin{array}{c}\text { 区別お } \\
\text { び年度 }\end{array}$} & \multicolumn{2}{|c|}{ 対 照 区 } & \multicolumn{2}{|c|}{ フッ素区 } \\
\hline & & & 1965 & 1966 & 1965 & 1966 \\
\hline - & 番 & 茶 & $\begin{array}{c}\mathrm{ppm} \\
192\end{array}$ & $\begin{array}{c}\mathrm{ppm} \\
138\end{array}$ & $\begin{array}{c}\mathrm{ppm} \\
301\end{array}$ & $\overline{\mathrm{ppm}}$ \\
\hline 二 & 番 & 茶 & 85 & 183 & 134 & 248 \\
\hline$\equiv$ & 番 & 茶 & 126 & 240 & 158 & 284 \\
\hline
\end{tabular}

表 13 完全抽出後の残留フッ素量

\begin{tabular}{|c|c|c|c|c|c|}
\hline 茶 & 期 & & 対 & 照 区 & フッ素区 \\
\hline - & 番 & 茶 & & 28 & ${ }_{25}^{\mathrm{ppm}}$ \\
\hline 二 & 番 & 茶 & & 20 & 21 \\
\hline$\equiv$ & 番 & 茶 & & 25 & 22 \\
\hline
\end{tabular}

注 : 1965年

表 14 全可溶分之多重段浸出残留物の 可溶分およびフッ素含量

\begin{tabular}{|c|c|c|c|c|c|c|c|}
\hline \multirow{2}{*}{ 区 別 } & \multirow{2}{*}{$\begin{array}{l}\text { 抽 } \\
\text { 出 } \\
\text { 筒 }\end{array}$} & \multicolumn{2}{|c|}{ 一 番 茶 } & \multicolumn{2}{|c|}{ 二番茶 } & \multicolumn{2}{|c|}{ 三番 茶 } \\
\hline & & 可溶分 & 娽畠 & 可溶分 & 素畺 & 可溶分 & 美皇 \\
\hline \multirow{4}{*}{ 対照区 } & 原料 & 43.3 & $\begin{array}{c}\mathrm{ppm} \\
192\end{array}$ & $40 . \%$ & $\begin{array}{l}\text { ppm } \\
85\end{array}$ & $\begin{array}{r}96 \\
43.3^{\circ}\end{array}$ & $\frac{\mathrm{ppm}}{126}$ \\
\hline & 2 & 23.4 & 38 & 24.3 & 34 & 17.1 & 31 \\
\hline & 3 & 25.0 & 47 & 26.7 & 46 & 17.3 & 36 \\
\hline & 4 & 27.2 & 46 & 28.2 & 46 & 19.2 & 35 \\
\hline \multirow{4}{*}{ フッ素区 } & 原料 & 43.4 & 301 & 41.8 & 134 & 43.1 & 158 \\
\hline & 2 & 21.2 & 36 & 24.3 & 38 & 23.6 & 52 \\
\hline & 3 & 23.3 & 52 & 23.7 & 41 & 27.3 & 60 \\
\hline & 4 & 19.5 & 43 & 28.3 & 43 & 28.3 & 44 \\
\hline
\end{tabular}


表 15 溶剤による測定結果

\begin{tabular}{|c|c|c|c|c|c|c|c|c|c|c|c|c|c|}
\hline \multirow{2}{*}{ 年度 } & \multirow{2}{*}{ 区別 } & \multirow{2}{*}{ 茶 期 } & \multirow{2}{*}{ 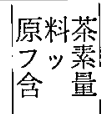 } & \multicolumn{2}{|c|}{$I-テ ル$} & \multicolumn{2}{|c|}{ n-ブタノール } & \multicolumn{2}{|c|}{ 酢酸エチル } & \multicolumn{2}{|c|}{ アルコール } & \multirow{2}{*}{\multicolumn{2}{|c|}{$\frac{\text { 水 }}{\text { 抽出液 残留物 }}$}} \\
\hline & & & & 抽出液 & 残留物 & 抽出液 & 残留物 & 抽出液 & 残留物 & 抽出液 & 残留物 & & \\
\hline \multirow{4}{*}{1966} & \multirow{2}{*}{ 対照区 } & 二番茶 & $\begin{array}{l}\mathrm{ppm} \\
183\end{array}$ & ppm $^{-}$ & $\begin{array}{c}\text { ppm } \\
105\end{array}$ & $\begin{array}{l}\text { ppm } \\
89\end{array}$ & $\begin{array}{l}\text { ppm } \\
115\end{array}$ & $\begin{array}{l}\text { ppm } \\
66\end{array}$ & $\mathrm{ppm}_{133}$ & $\begin{array}{c}\text { ppm } \\
106\end{array}$ & $\begin{array}{l}\text { ppm } \\
94\end{array}$ & $\begin{array}{c}\mathrm{ppm} \\
115\end{array}$ & 72 \\
\hline & & 三番茶 & 240 & $\dot{-}$ & 139 & 86 & 173 & 79 & 172 & 130 & 154 & 168 & 98 \\
\hline & \multirow{2}{*}{ 䚄区 } & 二番茶 & 248 & - & 124 & 93 & 160 & 77 & 145 & 123 & 96 & 114 & 95 \\
\hline & & 三番茶 & 284 & - & 160 & 101 & 194 & 74 & 200 & 128 & 157 & 184 & 100 \\
\hline \multirow{3}{*}{1967} & \multirow{3}{*}{ 䒺区 } & 一番茶 & 120 & 48 & 55 & 56 & 65 & 71 & 45 & 72 & 58 & 118 & 23 \\
\hline & & 二番茶 & 149 & 61 & 79 & 70 & 86 & 89 & 74 & 82 & 79 & 146 & 19 \\
\hline & & 三番茶 & 152 & 63 & 72 & 82 & 92 & 102 & 72 & 94 & 79 & 135 & 34 \\
\hline
\end{tabular}

表12に上る之，茶葉のフッ菜含量はほ場においてもポ ット裁培と同様，フッ素の施用によって増加することが 認められた。また，一般分析の方法で完全抽出すると，

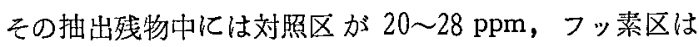
21 25 ppm が残留し，処理による含量の違いには関係 なく溶出するものと思われる。

多重段浸出に上る結果（表14）は，可溶分の残存割合 に比べ，フッ素の残留率は少なく，また，含量の多い屯 のほど溶出量が多かった。なお，茶殼には全体的に30 $60 \mathrm{ppm}$ が残り，62〜88\%が溶出した。

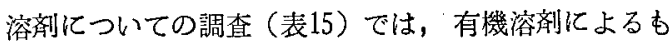
のより，水（熱湯）によるほうがフッ素の浸出量が多 く，また，有機溶剂ではアルコールへの溶出が多いよう に思われる。また，それぞれの溶出割合は熱晹で55 88 \%, nーブタノールが35〜47\%, 醀酸エチルが27〜60\%, アルコールが45〜60\%，エーテルが40〜50\%であった。

\section{6 要}

\section{約}

茶化含まれるフッ素の利用を図るため，1963～1967年 にフッ素の定量方法，茶のフッ素含量，また，施肥なら びにフッ菜施用によるフッ素含量の相違および，熱湯浸 出と有機溶剤によるフッ素溶出量について検討した。そ の結果を要約すれば次のでとくである。

1）フッ素は Th-Neo-Thorin 比色法で定量したが, その結果は, 回収率では99\%以上が得られ，焼却温度は $600^{\circ} \mathrm{C}$ が適当と思われた。

2）種々の無機質窒素肥料の施用が茶のフッ素含量に 及ぽす影響はみられなかったが，過リン酸石灰を施用し た場合には、フッ菜含量が多くなっていた。

3）茶のフッ素含量は若芽より毛成葉に多く，成熟に 伴い增加することが認められ，特に古葉に多いととが明 らかとなった。

4）茶樹のフッ素含量を器官別にみると, 葉に最も多
く，茎と根は大差がなかった。

5）多重段浸出によってインスタント ティーをつく り，固形分当たりのフッ素含量を調べたところ，茶種に よって異なるが, 150〜500 ppm が含まれていた。

6）や㚙きたははつもみじ，へにほまれをポットで栽 培し，フッ素施用の効果を検討した結果，フッ素の施用 と無施用との間に明らかな差があり，フッ素の施用によ り茶葉中にフッ素が著しく增加するととが認められた。

7）フッ素の溶剂に対する溶解度を検討した結果，有 機溶剂と熱湯では，熱湯によるほうがフッ菜の溶出量が 多く，全体の60 80\%が，また，有機溶剤ではアルコー ルに50〜60\%，エーテルには40〜50\% 溶解するととが判 明した。

水溶性のフッ素，あるいは残留フッ菜の直接的利用方 法については，一例として虫歯の予防などが考えられる が，われわれの研究としては困難な問題む多いと考えら れるので，乙れらの問題は利用方面の尃門家に任せるこ ととした。

この研究の遂行に当たってで指導をいただいた，静岡 女子短期大学学辰松浦新之助氏，ライオン崡磨研究所斉 藤浩氏，ならびに，試料をいただいた当場土袞肥料研究 室石垣幸三，高柳博次両技官に感謝する。

\section{7 参 考 文 献}

1) Sinnosuke Matuura, Nobuhide Koxubu, Sakuro WAKIMOTO, and Motowo TокіMASA : Depavtment of Chemistry, Faculty of Science, Kyushu Univ. C, 2 11) 37 46 (1954).

2）国分 信，梄崎 武，松浦新之助：日化誌，80, (12)；87 88 (1959).

3）江見浩一，速水 萛：日化誌，76(11)，97～99 
(1955).

4) Gunther, F. A. and R. C. Blinn : Anarysis of Insecticides and Acaricides, 6 Intersience Publishers, lnc., NEW YORK 460 (1955),

5）江見浩一，速水 毫：日化誌，77(11)，25２6 (1956).

6）河合惣吾，石坦幸三，岡本暢夫：茶技研，No，9， 10 (1953).

7）河合惣吾，石垣幸三，高柳博次：茶技研, No. 24, 26 (1961).

8）林 義三: 肥料の成分表, p. 134 135, 肥料研究 会 (1953).

9）故讃井 元, 中山 仰, 加納照崇, 酒井慎介：茶 試研報, No: 4. $2 \sim 5$ (1967).

10）古谷弘三, 原 利男, 久保田悦郎：茶技研, No. 27, 47 (1963).

11）古谷弘三，原利男; 久保田悦䬦：茶技研, No. 27,56 (1.963).

\section{Surnmary}

Fluorine content of several organs of tea plant (bud, young leaf, mature leaf, stem and root) was determined by the colorimetric method with thorium-neothrin. The effect of supplying sodium fluorine on the fluorine content of tea leaf, and the extracting rate of fluorine from tea with water and organic solvents were also investigated.

It was found that the fluorine content of tea leaf increased about $2 \sim 6$ times by supplying sodium fluoride in both pot and field culture and fertilizing superphosphates also increased the content, in comparison with inorganic nitrogenous fertilizers.

All parts of tea plant contained some quantity of fluorine and especially. the mature leaf contained the most of all. No significant difference of the content was observed between the stem and the root.

Upon standing for 24 hours at room temperature, fluorine in tea was extracted about $60 \sim 80 \%, 50 \sim 60 \%$ and $40 \sim 50 \%$ of the total with hot water, ethanol and ethyl ether, respectively.

Instant tea, made from fluorine-enriched tea leaves by feeding with sodium fluoride, contained $150 \sim 500$ p..p. m. of fluorine.

(Aug., 5, 1968) 